\title{
Model Sosialisasi Pemilihan Presiden 2019 di Komisi Independen Pemilihan Kota Banda Aceh
}

\section{Socialitation Model for the 2019 Presidential Election at the Banda Aceh City Independent Election Commission}

\author{
Siti Hardiyanti*, Muryanto Amin \& Warjio \\ Magister Ilmu Politik, Fakultas Ilmu Sosial Dan Ilmu Politik, Universitas Sumatera Utara, \\ Indonesia \\ Diterima: 27 Agustus 2020; Disetujui: 24 Desember 2020; Dipublish: 31 Januari 2021
}

\section{Abstrak}

Penelitian ini menjelaskan bagaimana model sosialisasi yang dilakukan oleh KIP Kota Banda Aceh pada Pemilu 2019 sebagai upaya untuk memberikan pemahaman pemilu kepada masyarakat. pelaksanaan model sosialisasi bekerjasama dengan berbagai komunitas/organisasi sangat ditingkatkan. Teori yang digunakan adalah teori sosialisasi, S.N Eisentadl dengan konsep-konsep yang digunakan komunikasi informasi berdasarkan dua model: model sosialisasi partisipatif dan model sosialisasi represif. Penelitian ini menggunakan metode kualitatif dengan wawancara sebagai teknik utama pengumpulan data kemudian data yang sudah diperoleh dianalisis secara konten. Hasil penelitian model sosialisasi yang dilakukan KIP bentuknya adalah kerjasama (socialization cooperation) dengan berbagai organisasi/komunitas, yang meliputi: KIP LSM Radar, KIP GPS, KIP ke BEM Unsyiah, Sosialisasi ke basis keluarga, sosialisasi ke KPI. Komunikasi informasi dilakukan oleh KIP dalam konteks kerjasama dengan mitra kerja. Ketika sosialisasi dilakukan atas inisiatif organisasi serta hadir ketempat sosialisasi secara sukarela maka sosialisasi tersebut dikategorikan pada model sosialisasi partisipatif. Sedangkan konsep komunikasi informasi sifatnya berjenjang dari nilai-nilai politik serta perasaan politik dikaji dari materi yang disampaikan oleh KIP yang mencakup materi pendidikan politik, seperti: hak dan kewajiban warga negara, tatacara mencoblos, pengenalan kertas surat suara, pengecekan DPT, serta tatacara pengurusan Form A5. implikasinya terhadap pemahaman masyarakat Kota Banda Aceh sudah memahami dan terpola kesadaran tentang materi sosialisasi yang disampaikan oleh KIP.

Kata Kunci: Sosialisasi, Pemilihan Presiden, Komisi Independen Pemilihan

\begin{abstract}
This research explains how the socialization model carried out by the Banda Aceh KIP in the 2019 Election is an effort to provide an understanding of the election to the public. the implementation of the socialization model in collaboration with various communities / organizations is greatly enhanced. The theory used is the socialization theory, S.N. Eisentadl, with the concepts used in information communication based on two models: the participatory socialization model and the repressive socialization model. This study used a qualitative method with interviews as the main technique of data collection, then the data that had been obtained were analyzed in terms of content. The results of the research on the socialization model carried out by KIP are in the form of cooperation (socialization cooperation) with various organizations / communities, which include: KIP LSM Radar, KIP GPS, KIP to BEM Unsyiah, Socialization to the family base, socialization to KPI. Information communication is carried out by KIP in the context of cooperation with working partners. When the socialization is carried out on the initiative of the organization and is present at the place of socialization voluntarily, the socialization is categorized as a participatory socialization model. Whereas the concept of information communication is tiered from political values and political feelings studied from the material presented by KIP which includes political education material, such as: citizens' rights and obligations, voting procedures, introduction of ballot papers, checking DPT, and procedures for administering Forms. A5. The implication is that the people of Banda Aceh already understand and have a pattern of awareness of the socialization material delivered by KIP

Keywords: Socialization, Presidential Election, Independent Election Commission
\end{abstract}

How to Cite: Hardiyanti, S. Amin, M. \& Warjio. (2021). Model Sosialisasi Pemilihan Presiden 2019 Di Komisi Independen Pemilihan Kota Banda Aceh. PERSPEKTIF, 10 (1): 160-170

*Corresponding author:

ISSN 2085-0328 (Print)

E-mail: sitihardiyanti@gmail.com ISSN 2541-5913 (online) 


\section{PENDAHULUAN}

Pemilu di Indonesia pertama kali terjadi pada tahun 1955 yang pada saat itu terkenal dengan pemilu paling bersih dan anti kecurangan dengan dukungan para birokrat, pemilu pun dilaksanakan untuk pertama kalinya. (Roz, 2006). Salah satu ciri negara demokrasi adalah negara yang menjalankan pemilu sebagai bentuk pesta demokrasi rakyat yang dijalankan dengan keterbukaan dan memprioritaskan kepentingan masyarakat. Masyarakat yang apatis dalam pemilu merupakan masalah yang sangat krusial. maka untuk menyelesaikan permasalahan tersebut, diberikan tugas kepada suatu lembaga yang nantinya melalui tugas dan wewenangnya dapat menyelesaikan masalah tersebut melalui program-program sosialisasi.

Lembaga penyelenggara pemilu adalah KPU. secara umum KPU menjadi sebutan disetiap daerah yang terdapat di Indonesia kecuali Daerah Aceh. Berdasarkan UndangUndang Nomor 11 Tahun 2006 tentang pemerintahan Aceh serta Qanun Nomor 7 Tahun 2007 terkait dengan Penyelenggara Pemilihan Umum (Pemilu). Maka berdasarkan kekhususan tersebut, sebutan yang berlaku di Aceh adalah KIP (Komisi Independen Pemilihan) yang meliputi KIP Aceh serta KIP Kabupaten/Kota. KIP Kota Banda Aceh dibentuk pada tahun 2003. Masing-masing KIP tersebut diberikan kewenangan oleh UndangUndang untuk menyelenggarakan Pemilu serta Pemilukada di seluruh wilayah Aceh.

Pemilihan umum tidak dilakukan secara bersamaaan, terlebih dahulu pileg yang diselenggarakan, baru kemudian disusul oleh pilpres yang diselenggarakan 3 bulan setelah pileg seperti yang dilakukan pada pemilu 2014. Pelaksanaan pemilu dilakukan dengan cara terpisah sangat kurang efektif karena akan berdampak terjadinya politik uang, siklus konflik politik yang panjang, politisasi birokrasi serta pemborosan dana. Berdasarkan hal tersebut Mahkamah Kostitusi mengeluarkan putusan nomor 14/PUU-XI/2013 terkait dengan pengujian undang-undang Nomor 42 tahun 2008 tentang Pemilihan Umum Presiden dan Wakil Presiden yang selanjutnya putusan Mahkamah Konstitusi 2013, yang berdampak kepada diselenggarakan pemilu secara serentak pada tahun 2019 (Solihah, 2019)

Hal utama yang sangat diperhatikan terselenggaranya pemilu dengan sukses adalah berhasil atau tidaknya cara sosialisasi yang dilakukan oleh KPU/KIP, model sosialisasi yang dilakukan tetap mengacu pada PKPU No. 10 Tahun 2018 yang bertujuan untuk memberikan pemahaman pemilu kepada masyarakat. Sosialisasi oleh KPU sudah pernah dilakukan oleh Penulis lainnya. diantaranya sebagai berikut: Pertama, sosialisasi dengan menggunakan perancangan infografik sebagai media pendukung sosialisasi KPU ke daerah terpencil. (Putra, 2019)

Kedua, sosialisasi dengan menggunakan pembangunan portal informasi political references sebagai media sosialisasi dan interaksi masyarakat dengan calon legislatif (Mohammad Arda Dwi Ardianto.dkk, 2019). Ketiga, sosialisasi dengan melibatkan organisasi serta bahan ajar siswa untuk memberikan pengatahun pemilu kepada masyarakat. seperti halnya memasukkan pendidikan politik dalam hal pengetahun tentang tugas dan kewajiban penyelenggara pemilu dalam mata pelajaran pendidikan kewarganegaraan (Putra A. D., 2016). keempat, partisipasi politik yang dilihat berdasarkan jejaring sosial dalam konteks komunitas sisilia (D'Agata, 2010 ). Kelima, partisipasi yang ditinjau dari berita online, kepercayaan di media, serta efek moderasi (Alberto ArdevolAbreu, Catherine M. Hooker , \& De zuniga, 2017). Selanjutnya yang terakhir adalah partisipasi politik yang ditinjau dari komodifikasi dan Digital berdasarkan gerakan 15-M dan kolektivisasi internet (CordobaHernandez, 2018).

Suksesnya sosialisasi menjadi garda terdepan suksesnya pemilu di suatu negara demokrasi karena hasil dari sosialisasi berpengaruh cukup besar terhadap pemahaman pemilu masyarakat. Sosialisasi sebagai salah satu cara untuk menimalisir terjadinya golput. untuk itu KIP memaksimal perannya untuk meningkatkan kepedulian masyarakat dalam pemilu melalui dilakukannya sosialisasi yang tentunya dengan cara-cara yang mudah dipahami oleh masyarakat karena esensi dari sosialisasi bertujuan untuk itu. Dalam konteks sosialisasi, model sosialisasi yang dilakukan pada Pemilu 2014 dan Pemilu 2019 sama saja modelnya hanya terdapat sedikit perbedaan dalam konteks cara melakukan sosialisasi, pada Pemilu 2014 tidak adanya sosialisasi yang disampaikan melalui cara-cara yang kekinian 
seperti sosialisasi melalui ngopi, selanjutnya pada Pemilu 2014 minimnya kerjasama sosialisasi yang dilakukan KIP dengan berbagai LSM dan Komunitas. Sedangkan pada Pemilu 2019 justru sebaliknya, sosialisasi digencarkan massif dengan melibatkan LSM atau organisasi. Gencarnya sosialisasi diharapkan berimplikasi bagus terhadap pengetahuan masyarakat terhadap pemilu. jadi sosialisasi dilakukan bukan hanya untuk formalitas saja.

Hal tersebut merupakan permasalahan yang diteliti dalam konteks sosialisasi pemilu, agar esensi dari sosialisasi tersampaikan secara menyeluruh kepada masyarakat. Sebelum sosialisasi dilakukan, KIP telah memetakan target dan dengan cara seperti apa sosialisasi akan disampaikan. Sasarannya kepada masyarakat umum, anak muda, kelompok marginal, lintas organisasi serta komunitas dengan menyampaikan sosialisasi mengikuti tren terkini yaitu sosialisasi di warung kopi untuk anak muda dan sosialisasi secara langsung ke tempat tertentu.

Model sosialisasi seperti itu dilakukan tujuannya adalah agar masyarakat memahami substansi pemilu, sehingga sosialisasi berguna untuk memberikan wawasan pemilu kepada masyarakat terkait dengan haknya sebagai warga negara sehingga tidak apatis/golput terhadap pemilu, dimana hal tersebut menjadi goals dari sosialisasi. Materi yang disampaikan adalah materi informasi kepemiluan sehingga diharapkan dapat mengubah pola pikir masyarakat dari sikap apatis menjadi optimis terhadap pemilu. Sosialisasi merupakan bentuk pengajaran nilai kepada masyarakat sehingga berpengaruh kepada aktif atau tidak masyarakat tersebut dalam suatu negara (Mohtar Mas'oed, 2001).

KIP Banda Aceh berusaha untuk mengubah pola pikir masyarakat Banda Aceh dengan penyampaian informasi pemilu melalui sosialisasi bahwa kepedulian masyarakat terhadap pemilu. Sosialisasi pemilu dilakukan tujuannya adalah untuk memberikan pemahaman pemilu kepada masyarakat sehingga materi yang disampaikan adalah materi informasi kepemiluan sehingga diharapkan dapat mengubah pola pikir masyarakat dari sikap apatis menjadi optimis terhadap pemilu. Cara sosialisasi yang dilakukan KIP dengan memanfaatkan wadah seperti tarian budaya, serta kerjasama dengan lintas organisasi/komunitas. Misalnya seperti sosialisasi kepada pemuda subuh yang tergabung dalam GPS melalui ngopi, dan sosialisasi kepada salah satu kelompok perempuan yang berpengaruh seperti Koalisi Perempuan Indonesia (KPI). KIP melakukan sosialisasi dengan mengikuti tren terkini. jadi masyarakat terutama kaum millenial diberikan ruang yang bebas untuk berkreasi sehingga berpengaruh terhadap sikap politiknya.

Berdasarkan penjelasan tersebut, Peneliti ingin mengkaji secara mendalam terkait dengan model sosialisasi yang dilakukan KIP pada Pilpres 2019. Penelitian ini dilakukan bertujuan untuk menjelaskan model sosialisasi yang dilakukan KIP yang bertujuan untuk memberikan pemahaman pemilu kapada masyarakat Kota Banda Aceh pada Pilpres 2019.

\section{METODE PENELITIAN}

Jenis penelitian yang digunakan adalah penelitian kualitatif (Suyanto \& Sutinah, 2005). Karena dengan menggunakan jenis penelitian tersebut bisa secara mudah mewawancarai informan dilapangan dengan mengkaji persoalan secara fenomenologis yang dapat memudahkan untuk memperoleh data melalui pengalaman, dan prilaku informan baik secara lisan maupun tulisan. Kemudian wawancara juga sangat efektif dilakukan, sebagai alat eksplorasi (Black \& J.Champion, 2009). Maksudnya adalah dengan melakukan penelitian secara kualitatif, dapat secara detail memperoleh informasi dari informan sehingga dapat membantu Peneliti untuk data penelitiannya. karena tujuan wawacara dilakukan adalah untuk memperoleh data dari pihak pertama (Usman \& Purnomo, 2009).

Pada penelitian kualitatif objeknya adalah manusia, dan penelitian kualitatif mampu memberikan informasi yang relatif pasti (Nawawi \& Martii, 2006). berdasarkan alasan itu tersebut juga digunakan jenis penelitian ini karena data serta informasi yang diperoleh lengkap dan mampu menjawab masalah yang diteliti.

Teknik pengumpulan data yang digunakan adalah menggunakan data primer dan data skunder. Dalam pengumpulan data primer alat riset hanya digunakan dengan dua alat: yaitu wawancara serta observasi. Wawancara secara mendalam merupakan hal yang harus dilakukan oleh periset dan juga informan, dimana nantinya jawaban responden 
akan menjadi data mentah yang kemudian digunakan oleh periset sebagai data untuk memperkuat masalah penelitiannya (Harrison, 2009).

Sedangkan data skunder terdiri dari dokumen, media massa, dan laporan. Menganalisis model sosialisasi Pemilihan Presiden yang ditinjau dari segi respon masyarakat tentang inovasi sosialisasi Pilpres 2019 di Komisi Independen Pemilihan Banda Aceh tentu harus melakukan wawancara langsung ke lapangan agar dapat memahami secara langsung persoalan yang terjadi dilapangan.

Informan menjadi penting bagi penelitian ini untuk memahami permasalahan secara detail permasalahan di lapangan, dalam penelitian kualitatif informan dapat dibagi 3 yaitu: Informan kunci, Informan utama dan Informan Pendukung (Suyanto \& Sutinah, 2005). Informan yang dipilih adalah informan yang memahami permasalahan yang akan dikaji (Martono, 2016).

Berikut data Informan yang dapat memberikan informasi dan bersedia menjadi narasumber: 1) Informan Kunci: Indra Milwady, S.Sos: Ketua KIP Kota Banda Aceh dan Ketua Divisi Sosialisasi, Pendidikan Pemilih, Partisipasi Masyarakat dan SDM KIP Kota Banda Aceh: Yusri Razali, S.Pd.I., ; 2) Informan Utama: Akademisi yaitu Zainal Abidin; 3) Informan Pendukung; Masyarakat yang tergabung dalam komunitas LSM Radar; Masyarakat yang tergabung dalam komunitas Gerakan Pemuda Subuh (GPS); Mahasiswa yang tergabung dalam organisasi mahasiswa (BEM Unsyiah); Masyarakat yang tergabung dalam komunitas KPI; Masyarakat yang tergabung dalam kelompok sosialisasi berbasis keluarga; Mahasiswa yang mengikuti acara stand up comedy.

Teknik analisis data dengan konten seperti yang dikatakan oleh Craswell dalam (Mantra, 2004). Analisis konten merupakan cara yang tepat digunakan untuk menjawab permasalahan yang diteliti, dari analisis konten juga dapat menganalisis teks secara sistematis (Ishiyama \& Breuning, 2013). Informasi yang diberikan oleh Narasumber berdasarkan peristiwa dan fakta yang terjadi, sehingga setelah informasi dan data diperoleh, maka selanjutnya adalah mengalisisnya secara konten agar dapat menjawab permasalahan yang diteliti.

\section{HASIL DAN PEMBAHASAN \\ Pelaksanaan Pemilhan Presiden (Pilpres) 2019 di Banda Aceh}

Partisipasi politik Masyarakat Banda Aceh pada Pilkada Tahun 2006 hanya 59.41\%, 2012 56.32\%, dan 2017 63.92\%. sedangkan untuk Pemilu Legislatif partisipasi masyarakat pada Pemilu 2009 hanya 60.19\%, Pemilu 2014 $62.00 \%$. kemudian pada Pada Pilpres 2009 partisipasi 63.41\%, Pilpres 2014 53.00\% (KIP Kota Banda Aceh, 2020). berbeda halnya dengan Pemilu 2019 yang tingkat partisipasinya sangat tinggi dari tahun sebelumnya yaitu $78.63 \%$. berdasarkan data yang disajikan di atas dapat dikatakan bahwa tingkat partisipasi masyarakat mengalami fluktuatif dari setiap pemilu. Hal tersebut dapat dikaji dari beberapa penyebab krusial, diantaranya adalah: persoalan keamanan, politik uang, kesadaran politik masyarakat yang minim, kurangnya model sosialisasi yang dilakukan oleh pihak penyelenggara menjadi faktor utama yang mendorong tingkat partisipasi Masyarakat Kota Banda Aceh.

Pemilu 2019 merupakan tingkat partisipasi tertinggi sepanjang sejarah, Sosialisasi yang dilakukan oleh KIP dilakukan sampai ke tingkat paling bawah disamping itu tugas parpol, akan tetapi KPU juga memiliki tugas untuk mensosialiasikan pemilu kepada masyarakat agar masyarakat paham dengan model pemilu serentak tersebut, karena bukan hal mudah untuk masyarakat mencoblos lima kertas surat suara, mengenal masing-masing calon legislatif maupun eksekutif dengan jumlah yang tidak sedikit. Hal tersebut menjadi tugas bersama untuk menggencarkan sosialisasi yang dilakukan oleh KPU pusat maupun KPU daerah.

Seluruh KPUD termasuk KIP Kota Banda Aceh dihimbau untuk meningkatkan partisipasi pemilih pada Pemilu 2019. Meningkat atau tidaknya partisipasi pemilih salah satu indikatornya bisa dilihat pada sosialisasi yang dilakukan oleh KIP disamping oleh pengaruh dari sosok calon pemimpinnya. Pada Pemilu 2019, isu Pilpres merupakan hal yang sering dibicarakan oleh kalangan masyarakat. Pasangan 01 Jokowi Widodo-Ma'aruf Amin dan Pasangan 02 Prabowo Subianto-Sandiaga Uno yang bertarung memperebutkan kursi eksekutif berhasil menarik perhatian masyarakat dengan masing-masing figur 
politik yang dimiliki. Persaingan dari kedua kubu pun tidak pernah luput dari pemberitaan media sehingga ada kesan tersendiri bagi masyarakat untuk memilih atau tidak.

Pemahaman masyarakat terkait dengan Pilpres lebih menonjol daripada Pileg. Calon Pilpres hanya ada dua pasangan kubu, sedangkan Pileg Calon Legislatifnya banyak sehingga membingungkan masyarakat untuk memilih. Jadi pada Pemilu 2019, sangat terlihat hanya terfokus pada Pilpresnya saja sedangkan isu Pileg terlihat biasa saja. sangat terlihat di salah satu TPS Banda Aceh ketika interaksi masyarakat pada saat pemungutan suara berlangsung, masyarakat hanya membicarakan soal pasangan calon pada Pilpresnya saja dan lebih mengenal pasangan calon tersebut. tidak hanya itu saja, rasa penasaran masyarakat pun terlihat pada saat sosialisasi berlangsung.

Salah satu hal yang membuat masyarakat tertarik untuk datang ke tempat sosialiasasi adalah karena isu Pilpres, masyarakat ingin melihat pada saat sosialisasi berlangsung, seperti apa sikap netral KIP pada Pemilu 2019, apakah dari pihak KIP ada membahas tentang Pilpres dan mengarahkan masyarakat untuk fokus ke Pilpresnya saja atau KIP netral hanya membahas terkait dengan tata laksana pemilu yang mencakup jadwal pemungutan suara, mengecek masyarakat terdapat atau tidak di DPT, tata cara mencoblos, serta pengenalan 5 kertas surat suara. jadi alasan tersebut yang mendorong masyarakat untuk ikut hadir di tempat sosialiasasi meskipun argumen itu tidak benar. Pada saat sosialiasi berlangsung, ternyata sikap dari KIP netral, tidak menggiring masyarakat untuk mendukung pasangan calon tertentu, KIP melakukan sosialisasi sesuai dengan aturan yang telah berlaku, (Wawancara dengan Ridho Sampriadi di Banda Aceh selaku Mahasiswa)

Hal yang terpenting sosialisasi dilakukan adalah untuk memberikan pemahaman kepada masyarakat terkait dengan hak pilihnya, kemudian menjelaskan terkait dengan pemilu apa saja yang akan dilakukan pada pemilu 2019, menjelaskan kepada masyarakat tata cara memlih serta memberitahukan kepada masyarakat agar terdaftar pada DPT (wawancara Indra Milwady di Banda Aceh selaku Ketua KIP Banda Aceh).

Pemahaman masyarakat terkait dengan pemilu tergantung pada tingkat pendidikan masing-masing masyarakat. umumnya, masyarakat yang sudah paham dengan situasi politik cendrung lebih berpikir secara logis terhadap suatu informasi yang sedang berkembang yang dipengaruhi oleh pemberitaan media, dengan tidak langsung menyimpulkan terhadap suatu informasi tersebut. Akan tetapi terlebih dulu mencari tau secara detail kebenaran informasi tersebut dengan cara terlibat langsung sebagai peserta sosialisasi. Hal yang demikian menjadi faktor utama masyarakat datang ke tempat sosialisasi. kemudian hal yang selanjutnya diperhatikan adalah substansi. Materi kepemiluan yang dijelaskan KIP kepada masyarakat secara umum mudah dipahami karena menyangkut informasi dasar terkait dengan pendidikan pemilih. Jadi tidak terdapat perbedaan desain sosialisasi antara Pileg dan Pilpres.

\section{Model Sosialisasi dengan berbagai Organisasi dan Komunitas}

Komunikasi informasi yang dilakukan KIP ke berbagai organisasi/komunitas sistematis agar sosialisasi dapat tersentuh ke setiap masyarakat dari tingkat penyelenggara ke komunitas sampai kepada tingkat lingkungan masyarakat. nilai-nilai politik yang disampaikan oleh KIP terkait dengan pendidikan pemilih bertujuan agar masyarakat memahami hak dan kewajibannya sebagai warga negara serta tidak apatis dalam penyelenggaraan pemilu. Model sosialisasi yang dfokuskan pada penelitian hanya di fokuskan pada lima model sosialisasi saja yaitu: sosialisasi melalui KIP goes to community (LSM Radar), KIP goes to comunnity (GPS), KIP goes to campus (BEM Unsyiah), sosialisasi ke forum keluarga, sosialisasi ke KPI.

Pada penelitian ini hanya membahas segmentasi berdasarkan keluarga, pemilih pemula, kaum marginal, pemilih muda serta pemilih perempuan. Karena kelima segmen tersebut merupakan sasaran atau peserta dari model sosialisasi yang difokuskan dan dibahas pada penelitian ini.

Sosialisasi yang dilakukan KIP melalui kerjasama dengan lintas komunitas atau organisasi sebagaimana yang telah disebutkan dalam PKPU. Organisasi tersebut merupakan mitra kerja KIP untuk mengencarkan sosialisasi ke berbagai lapisan masyarakat. Jadi penyampaian sosialisasi terstruktur dan sistematis. Pada tahap awalnya dilakukan kerjasama antara KIP dengan 
organisasi/komunitas, kemudian sosialisasi dilakukan baik dengan melibatkan KIP secara langsung maupun dilakukan secara mandiri ke berbagai segmen masyarakat.

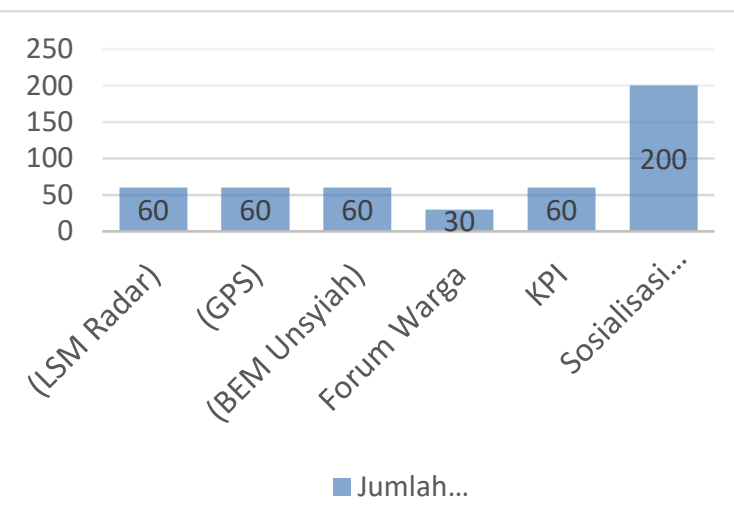

Gambar 1. Grafik Model Sosialisasi KIP Kota Banda Aceh

Sumber: KIP Kota Banda Aceh, 2019 (data diolah)

Teori sosialisasi yang dikemukakan oleh S.N. Eisentadl, komunikasi informasi sifatnya sistematis, pertama, dalam konteks koordinasi sosialisasi yaitu KIP mengajak kerjasama komunitas atau organisasi untuk sama-sama menggencarkan sosialisasi dengan berbagai model sosialisasi. kedua, komunikasi informasi dalam konteks materi yang disampaikan pada saat sosialisasi kepada peserta baik yang disampaikan oleh pihak penyelenggara maupun komunitas atau organisasi yang diajak kerjasama oleh KIP.

Cara penyampaian sosialisasi melalui komunikasi yang dilakukan oleh KIP berdampak kepada respon masyarakat termasuk kepada pola pikir masyarakat saat mengikuti kegiatan sosialisasi. nilai-nilai serta perasaan politik yang terdapat pada materi seperti halnya pendidikan pemilih disampaikan pada saat sosialisasi. intinya dari setiap kegiatan tersebut adalah memberikan pemahaman kepemiluan kepada masyarakat, meskipun dari setiap masyarakat yang diwawancarai memahami persoalan pemilu akan tetapi belum bisa dikatakan persoalan teknisnya. terselenggaranya pemilu serentak pada tahun 2019. pihak penyelenggara ditugaskan untuk mensosialisasikan pemilu.

Hal yang sangat perlu diperhatikan adalah persoalan teknisnya karena ketika masyarakat tau calon pemimpin yang akan dipilih tapi tidak mengerti tatacara memilih dengan benar maka suaranya dianggap tidak sah oleh karena itu KIP fokus melakukan sosialisasi ke berbagai segmentasi masyarakat dengan bekerjasama komunitas dan organisasi untuk sama-sama melakukan sosialisasi kepada masyarakat melalui model yang telah ditentukan. Berikut penjelasan model sosialisasi yang dilakukan oleh KIP bersama mitra kerjanya dengan menggunakan indikator yang digunakan pada teori sosialisasi.

KIP goes to community (LSM Radar), proses komunikasi informasi yang dilakukan oleh KIP dengan LSM Radar adalah dalam bentuk kerjasama yaitu KIP mengajak LSM Radar bekerjasama untuk melakukan sosialisasi kepada segmen yang telah ditentukan. Kemudian LSM Radar melakukan sosialisasi secara sukarela atau model sosialisasi partisipatif yang dilakukan kepada kelompok yang telah ditentukan oleh KIP. Selanjutnya setelah segmen tersebut memperoleh informasi materi kepemiluan, diharapkan dapat disampaikan kembali kepada lingkungannya. Jadi dapat dikatakan komunikasi informasi berjenjang untuk samasama mengencarkan sosialisasi Pemilu yang dimulai kerjasama awal yang dilakukan KIP dengan organisasi/komunitas.

Sosialisasi dalam konteks ini dilakukan melalui dua cara. Pertama, melalui diskusi sambil ngopi di warung kopi yang dipandu oleh KIP. Kedua, kegiatan sosialisasi selanjutnya dilakukan secara mandiri oleh LSM Radar kepada santri dan kelompok marginal berdasarkan sasaran sosialisasi yang telah ditentukan oleh KIP. Maka LSM Radar ditugaskan oleh KIP untuk mengencarkan sosialisasi sesuai dengan target yang telah di perintahkan oleh KIP.

Berdasarkan hasil wawancara yang telah dijelaskan oleh informan, dapat disimpulkan bahwa segmen yang difokuskan sosialisasi oleh LSM Radar adalah kepada segmen pemilih pemula serta kelompok marginal. Dalam konteks ini sosialisasi dilakukan dengan dua cara. Sosialisasi disampaikan tergantung kepada segmen pemilihnya. pertama, sosialisasi dilakukan oleh KIP bekerjasama dengan LSM Radar dengan cara ngopi karena segmen pemilihnya adalah pemilih millenial dan pemilih pemula, dimana pemuda indentik suka dengan nongkrong dan santai sambil menikmati kopi maka metode yang digunakan adalah sosialisasi melalui Ngopi atau ngobrol pemilu yang dilakukan di warung kopi dengan mengikuti trend anak muda saat ini. edukasi 
pemilu disampaikan dalam kegiatan tersebut yang berguna untuk mengawal pemilu serta mengajak politiknya.

pemilih menggunakan

hak

Tabel 1. Interaksi sosialisasi KIP dengan Mitra Kerja

\begin{tabular}{|c|c|c|}
\hline Interaksi sosialisasi & Peserta & Cara penyampaian sosialisasi \\
\hline $\begin{array}{lrr}\text { KIP } & \text { bekerjasama } & \text { dengan } \\
\text { LSM } & \text { Radar } & \text { untuk } \\
\text { menggencarkan sosialisasi }\end{array}$ & $\begin{array}{ll}\text { Santri, } & \text { mahsiswa } \\
\text { dan } & \text { kelompok } \\
\text { nelayan } & \\
\end{array}$ & $\begin{array}{l}\text { - Sosialisasi disampaikan dengan cara NGOPI } \\
\text { (ngobrol opini terkini) di warung kopi } \\
\text { - Sosialisasi disampaikan melalui diskusi }\end{array}$ \\
\hline $\begin{array}{l}\text { KIP bekerjasama dengan } \\
\text { komunitas GPS untuk } \\
\text { menggencarkan sosialisasi }\end{array}$ & $\begin{array}{ll}\text { Siswa dan } \\
\text { Masyarakat }\end{array}$ & $\begin{array}{l}\text { - Sosialisasi disampaikan dengan cara NGOPI } \\
\text { (ngobrol opini terkini) di warung kopi }\end{array}$ \\
\hline $\begin{array}{l}\text { KIP bekerjasama dengan } \\
\text { BEM Unsyiah untuk } \\
\text { menggencarkan sosialisasi }\end{array}$ & $\begin{array}{l}\text { Mahasiswa dan } \\
\text { Masyarakat }\end{array}$ & $\begin{array}{l}\text { - Sosialisasi disampaikan melalui seminar dan di } \\
\text { bukanya posko untuk pengurusan form A5 }\end{array}$ \\
\hline $\begin{array}{l}\text { KIP melakukan sosialisasi } \\
\text { ke Basis Keluarga }\end{array}$ & $\begin{array}{l}\text { Anggota KPPS dan } \\
\text { PPS }\end{array}$ & - Sosialisasi disampaikan melalui simulasi \\
\hline $\begin{array}{l}\text { KIP bekerjasama dengan } \\
\text { Anggota KPI }\end{array}$ & $\begin{array}{l}\text { Anggota KPI dan } \\
\text { Masyarakat }\end{array}$ & Sc \\
\hline
\end{tabular}

Selanjutnya yang kedua, sosialisasi dilakukan secara mandiri oleh LSM Radar. LSM Radar diberikan tugasnya untuk mengencarkan sosialisasi khususnya ke segmen kelompok marginal dan pemilih pemula yang ada di Dayah/Pondok Pesantren yang bertujuan untuk memberikan pemahaman kepada masyarakat informasi tentang pemilu jurdil (jujur dan adil).

KIP goes to community (GPS), Sosialisasi yang dilakukan KIP tidak hanya berkerjasama dengan LSM akan tetapi juga melibatkan komunitas pemuda yang tergabung ke dalam gerakan pemuda subuh atau GPS. Komunikasi informasi yang dilakukan KIP adalah bekerjasama dengan Anggota GPS dalam hal sosialisasi. jadi pada tahap awalnya KIP memanfaatkan moment shalat subuh untuk melakukan sosialisasi. Shalat subuh diikuti oleh jamaah yang diantaranya termasuk Anggota GPS, Siswa SMA serta masyarakat umum yang kemudian menjadi peserta pada sosialisasi.

GPS merupakan kelompok pemilih pemula yang didominasi oleh anak muda dan merupakan salah satu sasaran sosialisasi dari KIP. Komunikasi informasi pada saat KIP menyampaikan materi sosialisasi kepada peserta sosialisasi dapat dilihat berdasarkan pemahaman pesertanya, karena tujuan dari dilakukannya sosialisasi adalah agar memahami materi yang disampaikan kemudian terlibat aktif pada pemilu, hal yang menarik yang didapatkan anggota GPS dalam hal memahami nilai-nilai politik yang disampaikan dalam materi adalah: Kesadaran politik merupakan hal yang utama yang menjadi faktor pendorong hadirnya di tempat sosialisasi, walaupun kegiatan tersebut disampaikan dengan cara ngopi akan tetapi substansi dari materi juga merupakan hal yang penting untuk dipahami. Pada umumnya Masyarakat Kota Banda Aceh memiliki tingkat pendidikan yang bagus, melek terhadap teknologi sehingga literasi politiknya tinggi ini. oleh karena itu tidak heran ketika peserta hadir juga untuk menambah pengetahuannya tentang pemilu karena telah ada pemahaman sebelumnya. pemahaman pemilu menjadi hal yang mudah diterima oleh peserta.

Berdasarkan dari hasil wawancara dari informan dapat disimpulkan bahwa kegiatan sosialisasi dikoordinir oleh KIP dan GPS yang bertugas bersama-sama mengencarkan sosialisasi melalui ngopi (ngobrol opini terkini). Nama pertama kali komunitas GPS adalah Kompas atau komunitas pemuda subuh yang dibentuk pada tahun 2015 yang dipelopori oleh pemuda-pemuda Aceh serta Ormas Islam yang memiliki kesamaan visi dan misi yaitu ingin berperan aktif menyiarkan syariat islam dengan berdakwah ke setiap mesjid yang ada di Kota Banda Aceh serta Aceh Besar pada saat subuh. Komunitas ini fokus membahas kajian-kajian tentang Islam karena Aceh merupakan salah satu Provinsi yang menerapkan syariat Islam maka komunitas ini lahir untuk menyiarkan ajaran-ajaran Islam.

KIP goes to campus (BEM Unsyiah), sosialisasi ke BEM (Badan Eksekutif Mahasiswa) Unsyiah yang diadakan pada 
tanggal 05 Maret 2019 di Ruang Kaca, Gelanggang Mahasiswa Unsyiah. Komunikasi informasi dilakukan dalam bentuk kerjasama antara Bem Unsyiah bekerjasama dengan KIP dan kemudian disampaikan kepada mahasiswa untuk mengikuti kegiatan sosialisasi. tujuannya adalah untuk memberikan pemahaman pemilu kepada rekan-rekan mahasiswa. kegiatan sosialisasi merupakan inisiatif dari Bem Unsyiah yang mengajak KIP untuk sama-sama memberikan pemahaman pemilu kepada teman-teman mahasiswa. model sosialisasi tersebut dikategorikan ke dalam model sosialisasi partisipatif.

Berdasarkan hasil wawancara informan dapat disimpulkan bahwa kegiatan sosialisasi dilakukan atas dasar inisiatif Bem Unsyiah sehingga mengajak KIP bekerjasama untuk membantu menyampaikan sosialisasi kepada rekan-rekan mahasiswa, sosialisasi yang dilakukan tersebut termasuk pada model sosialisasi partisipatif kerena melakukan sosialisasi secara sadar dan sukarelawa dengan melibatkan orang lain tanpa adanya paksanaan dari pihak manapun. sosialisasi yang dilakukan terdiri dari dua rangkaian acara. Pertama, acara sosialisasi. kedua, pengurusan permohonan untuk mendapatkan form A5 sebagai syarat untuk pindah memilih. Upaya tersebut dilakukan tujuannya adalah agar mahasiswa tidak golput (golongan putih) walaupun tidak pulang ke kampung halamannya. para mahasiswa ini termasuk kepada pemilih pemula serta dikategorikan kepada kelompok millenial yang memiliki presentasi suara yang sangat besar yaitu sebagai penyumbang 35\% suara pada pemilu 2019. Hal tersebut dibuktikan dengan kahadiran serta antusias yang tinggi dari peserta yang hadir pada saat sosialisasi yaitu berjumlah 60 orang. KIP memfasilitasi kegiatan ini untuk memberikan edukasi pemilu kepada mahasiswa dengan cara menggaet mahasiswa menggencarkan sosialisasi.

Sosialisasi ke forum warga berbasis keluarga dilakukan pada setiap kantor Camat yang berada di seluruh Kota Banda Aceh. salah satunya adalah ke Kantor Camat Syiah Kuala yang dilaksanakan pada hari Rabu, 29 Agustus 2018 yang bertempat di Kantor Camat Syiah Kuala dan dihadiri oleh 30 orang peserta. Koordinasi komunikasi antara KIP sampai kepada tingkat petugas pemilu untuk melakukan sosialisasi sehingga cara penyampaian sosialisasi yang dilakukan KIP kepada basis keluarga khususnya kepada pihak kecamatan dengan cara melakukan sosialiasi hanya kepada petugas pemilu saja tanpa diikutsertakan masyarakat secara umum karena persoalan keterbatasan anggaran dan hal yang lainnya.

Materi yang telah diberikan pada saat sosialisasi kepada petugas pemilu, harus disampaikan kembali kepada masyarakat atau dengan kata lain petugas pemilu melakukan inisiatif pendidikan pemilih kepada masyarakat melalui komunikasi informasi yang disesuaikan dengan masyarakat, yang terdapat di setiap kecamatan agar masyarakat juga mengetahui setiap tahapan pada pemilu 2019. walaupun tidak menutup kemungkinan sebagian masyarakat sudah mengetahui berbagai tahapan dari informasi atau pihak lain yang menyelenggarakan. Agar sosialisasi lebih maksimal sampai kepada tingkat bawah maka sosialisasi harus dilakukan secara berjenjang. Seperti halnya memberikan informasi kepada masyarakat terkait pengecekan masyarakat terdaftar di DPT mana. Hanya dengan menggunakan nama lengkap yang di tulis di aplikasi DPT, maka masyarakat akan di cek terdata atau tidak di DPT. Jadi memudahkan masyarakat mengetahui dirinya terdaftar atau tidak sehingga masyarakat bisa memilih pada hari pencoblosan. Pengenalan penggunaan aplikasi DPT serta adanya simulasi merupakan salah satu hal yang menarik pada saat sosialiasasi berlangsung di Kantor Camat, dibuktikan oleh peserta yang hadir melebihi target yang direncanakan dan peserta sangat antusias mengikuti acara tersebut.

Sosialisasi ke koalisi perempuan indonesia (KPI), Pada segmen pemilih perempuan, KIP bekerjasama melakukan sosialisasi ke KPI Aceh, sehingga dari pihak KPI memberitahukan kepada anggotanya yang lain untuk mengikuti kegiatan sosialisasi dan kemudian kegiatan tersebut diikuti juga oleh masyarakat terutama kelompok Ibu-ibu, jadi komunikasi informasi dilakukan berjenjang agar semua pihak dapat menggunakan hak pilihnya dengan baik, sosialisasi dengan cara tersebut dapat dikategorikan kedalam model sosialisasi partisipatif karena dilakukan atas dasar kesadaran politik untuk mengecarkan sosialisasi agar informasi pemilu tersampaikan kepada masyarakat. 
Budaya patriaki masih melekat pada masyarakat Aceh saat ini sehingga ruang gerak perempuan masih terbatas. Untuk itu perlu adanya kesadaran politik masyarakat bahwa tidak selamanya stigma yang dilabelkan kepada perempuan itu benar, perempuan dapat menjadi pemimpin asalkan tidak menyalahi kodratnya sebagai perempuan. Maka tugas KIP adalah mensosialisasikan dengan mengedukasi masyarakat agar juga dapat mendukung perempuan maju sebagai calon legislatif dan dapat merubah pola pikir masyarakat ke arah yang lebih modern.

Implikasi penggunaan model sosialisasi kepada masyarakat, pada dasarnya tujuan dari sosialisasi adalah untuk memberikan pemahaman pemilu kepada masyarakat sehingga kemudian masyarakat sadar dengan hak politiknya. Berdasarkan cara-cara yang disampaikan melalui sosialisasi yang memperhatikan indikator yang telah ditentukan sehingga konsep yang akan dijawab adalah komunikasi informasi, nilai-nilai serta perasaan mengenai poltiik secara eksplisit. Perkembangan teknologi dan informasi yang signifikan menjadikan masyarakat perkotaan melek terhadap informasi. Realitanya saat ini masyarakat Kota Banda Aceh literasi politiknya tinggi berdasarkan hasil survey yang telah dilakukan oleh KIP Kota Banda Aceh. Umumnya masyarakat Kota Banda Aceh memahami serta tidak susah pihak penyelenggara memberikan pemahaman pemilu kepada mereka.

Komunikasi informasi yang dilakukan KIP melalui kegiatan sosialisasinya dengan menyampaikan materi kepemiluan kepada masyarakat agar masyarakat sadar dengan hak politiknya sehingga respon masyarakat yang hadir pada kegiatan tersebut sangat bagus. Sosialisasi pendidikan pemilih dilakukan oleh KIP intinya agar masyarakat memperoleh informasi tentang pemilu, menjelaskan jenis pemilu apa saja yang akan dilakukan, kemudian bagaimana memastikan /mengecek masyarakat terdaftar, selanjutnya bagaimana mereka menggunakan hak pilih. Jadi tema-tema dasar itu yang disampaikan kemudian KIP juga membawakan alat peraga seperti kertas surat suara agar masyarakat bisa lebih memahami. tidak menutup kemungkinan juga dilakukan simulasi pemungutan suara jika kondisinya memungkinkan.

Menurut informan kegiatan sosialisasi yang dilakukan sudah sangat efektif dan tersentuh ke semua segmen masyarakat. Akan tetapi tingkat dari segi kepuasan masyarakat terhadap kegiatan sosialisasi tidak bisa di ukur berdasarkan indikator, karena KIP tidak memiliki instrumen monev. Kepuasan masyarakat hanya diketahui dari pendapat langsung masyarakat dan informasi dari orang lain. Kegiatan sosialisasi yang lebih dari satu kegiatan dalam satu hari. Setiap anggota KIP dikerahkan untuk terjun ke berbagai lokasi sosialisasi agar space tidak kosong artinya bahwa semua masyarakat tersentuh. Dapat dikatakan dari hasil sosialisasi tersebut dapat berpengaruh yang cukup bagus terhadap kualitas pemilu. KIP melakukan sosialisasi sesuai dengan ketersediaan anggaran. Sosialisasi tidak hanya dilakukan secara formal saja akan tetapi juga secara non formal yaitu mengunjungi masyarakat di tempat mereka beraktifitas.

Kesadaran masyarakat terkait dengan hak politik terlihat peserta yang ikut hadir pada saat sosialisasi merupakan komunitas atau organisasi yang diajak oleh KIP untuk samasama mengencarkan sosialisasi, koordinasi komunikasi informasi yang dilakukan KIP dengan mitra kerjanya dalam konteks kerjasama, baik dilakukan secara mandiri oleh organisasi maupun melibatkan KIP secara langsung, mereka sebagai promotor sosialisasi maka sudah seharusnya mereka juga ikut memilih. Intinya mereka menyampaikan sosialisasi kepada masyarakat agar masyarakat memilih dengan memberikan pemahaman nilai-nilai politik melalui materi pendidikan pemilih sehingga pengenalan serta informasi kepemiluan massif diberikan akan tetapi jika organisasi tersebut tidak memilih itu menjadi pertanggungjawaban moril yang begitu besar terhadap masyarakat.

Ketika KIP menyampaikan materi sosialisasi, peserta memahami dengan jelas materi tersebut hanya saja menyangkut persoalan teknis yaitu pengurusan form A5 yang belum di pahami karena telat hadir pada saat sosialisasi. Masyarakat yang hadir pada saat sosialisasi, bukan dengan pikiran yang kosong tanpa informasi apapun yang sudah ada pada pikiran mereka. Para peserta sudah memiliki referensi sendiri, pemahaman sendiri dan ideologi sendiri yang telah di peroleh dari informasi yang beredar di media sosial yang telah mempengaruhi pemikiran peserta. 
Berdasarkan temuan peneliti dapat dipaparkan bahwa setiap orang dapat terpengaruh dengan kegiatan sosialisasi apabila orang tersebut tidak memiliki referensi atau pemikiran sendiri sehingga orang tersebut akan sadar dengan hak politiknya akan tetapi tidak menutup kemungkinan juga hal sebaliknya terjadi walaupun sudah memiliki referensi politik dari luar, masyarakat tersebut juga tidak menggunakan hak pilih karena belum memahami materi sosialisasi secara maksimal walaupun presentasenya kecil akan tetapi juga sangat berpengaruh terhadap tindakan politik seseorang.

\section{SIMPULAN}

Proses sosialisasi yang dilakukan adalah dengan cara memberikan informasi terkait dengan pengenalan 5 kertas surat suara, pengecekan masyarakat terdaftar atau tidak di DPT, tatacara mencoblos serta memberikan materi pendidikan pemilih. Model sosialisasi yang dilakukan oleh KIP adalah KIP goes to community dengan LSM Radar, KIP goes to community dengan GPS, KIP Goes To Campus ke BEM Unsyiah, sosialisasi ke forum warga serta sosialisasi ke KPI. beberapa program sosialisasi KIP dilakukan dengan cara yang berbeda. tergantung kepada target segmentasinya. Pada seluruh pembahasan model sosialisasi tersebut digunakan teori sosialisasi oleh S.N. Eisentadl dengan indikator yang digunakan adalah: informasi, perasaan serta nilai-nilai politik.

Hasil dari nilai-nilai politik yang disampaikan pada saat sosialisasi berdampak kepada respon Anggota KPI terhadap kegiatan sosialisasi yang dilakukan oleh KIP yang menurutnya kegiatan tersebut bagus karena memberikan pemahaman politik kepada masyarakat secara umum. Walaupun antusias peserta tinggi pada kegiatan sosialisasi yang dilakukan oleh KIP akan tetapi belum tentu berdampak kepada sikap politiknya. Teori yang digunakan pada pembahasan terkait dengan model sosialisasi. Pertama, komunikasi informasi dilihat berdasarkan bentuk kerjasama sosialisasi (socialization cooperation) dengan komunitas atau organisasi serta komunikasi dalam bentuk penyampaian materi kepada peserta pada saat agenda sosialisasi berdampak positif terhadap pemahaman pemilu peserta, sehingga peserta hadir karena kesadaran politiknya. Kedua, nilai- nilai atau perasaan politik yang terkandung dalam materi seperti pendidikan pemilih dapat dipahami dengan baik oleh peserta sosialisasi sehingga mereka menggunakan hak pilihnya, hanya saja persoalan teknis seperti simulasi pemilu perlu ditingkatkan agar substansi sosialisasi lebih mudah dipahami oleh peserta, karena menyangkut hak dan kewajiban warga negara, tatacara pencoblosan, pengenalan 5 kertas surat suara, pengurusan form A5.

\section{DAFTAR PUSTAKA}

Alberto Ardevol-Abreu, Catherine M. Hooker , \& De zuniga, H. G. (2017). Online news creation, trust in the media, and political participation: Direct and moderating effects over time. hal 1.

Arda Mohammad, D. A. (2019). Pembangunan Portal Informasi Political References Sebagai Media Sosialisasi dan Interaksi Masyarakat dengan Calon Legislatif. Jurnal Pengembangan Teknologi Informasi dan Ilmu Komputer, Vol. 3, Nomor 5 .

Black, J. A., \& J.Champion, D. ( 2009). Metode dan Masalah Penelitian Sosial. Bandung: PT. Refika Aditama.

Cordoba-Hernandez, M. J. (2018). Commodification and Digital Politics Participation: "15-M Movement" and Internet collectivization, . DOI: $10.5294 / 2018$.

Gozzo, S., \& Agata, R. D. (2010). Social Network and Political Participation In a Sicilian Community Context. Procedia Social And Behavioral Sciences, hal 49.

Harrison, L. (2009). Metode Penelitian Politik. Jakarta: PT. Fajar Interpratama Offset.

Ishiyama, T., \& Breuning, M. (2013). Ilmu Politik Dalam Paradigma Abad Kedua Puluh Satu Sebuah Referensi Panduan Tematis. Jakarta: Kencana Prenada Media Group.

Mantra, I. B. (2004). Filsafat Penelitian dan Metode Penelitian Sosial. . Yogyakarta: Pustaka Pelajar Offset.

Martono, N. (2016). Metode Penelitian Sosial, Konsep-konsep kunci. . Jakarta: PT.Raja Grafindo Persada.

Mohammad Arda Dwi Ardianto.dkk. (2019). Pembangunan Portal Informasi Political References Sebagai Media Sosialisasi dan Interaksi Msyarakat dengan Calon Legislatif. Jurnal Pengembangan Teknologi Informasi dan Ilmu Komputer., Vol 3 No.5, hal 4865.

Mohtar Mas'oed, d. C. (2001). Perbandingan Sistem Politik. Yogyakarta: Gadjah Mada University Press.

Nawawi, H., \& Martii, H. (2006). Instrumen Penelitian Bidang Sosial. Yogyakarta: Mada University Press. 
Siti Hardiyanti, Muryanto Amin \& Warjio, Model Sosialisasi Pemilihan Presiden 2019 Di Komisi

Putra, M. E. (2019). Perancangan Infografik sebagai media pendukung sosialisasi KPU ke daerah terpencil. Jurnal Seni Desain Dan Budaya, Vol 4. No.3, hal 82.

Robles, J. M., \& Cordoba-Hernandez, A. M. (2018). Commodification and Digital Politics Participation: "15-M Movement" and Internet collectivization. hal 992.

Roz, S. (2006). Zaman Bergerak, Birokrasi Dirombak, Potret Birokrasi dan Politik Indonesia. . Yogyakarta: Pustaka Pelajar.

Solihah, R. (2019). Peluang dan tantangan pemilu serentak. jurnal Ilmiah Ilmu Pemerintahan Vol.3 N0.1. hal 74. .
Strauss, A., \& Corbin, J. (2003). Dasar-Dasar Penelitian Kualitatif. . Yogyakarta: Pustaka Pelajar.

Suyanto, B., \& Sutinah. (2005). Metode Penelitian Sosial: Berbagai Alternati fPendekatan. . Jakarta: Prenanda Media.

Trissatya, P. d. (2016). Inovasi Model Sosialisasi Peran Serta Masyarakat Dalam Pemilu. Jurnal Wacana Politik, Vol 1. No. 2, hal 150.

Usman, H., \& Purnomo, A. S. ( 2009). Metedologi Penelitian Sosial. . Jakarta: PT Bumi Aksara. 